\title{
Activation of points of economic growth in the territory of the Republic of Bashkortostan
}

\author{
Olga Fedorova ${ }^{1, *}$, Shamil Valiev1, and Natalia Sukhankina ${ }^{2}$ \\ ${ }^{1}$ Ufa State Petroleum Technological University, Cosmonauts Str., 1, 450064 Ufa, Russia \\ ${ }^{2}$ Belarusian State Pedagogical University Named After Maxim Tank, Sovetskaya st., 18, 220050 \\ Minsk, Republic of Belarus
}

\begin{abstract}
Activation of points of economic growth in regions with a tendency of reduction in natural resources and labor potential contributes to development of territories. The article presents an analysis of the natural resources, production and labor potential of the Republic of Bashkortostan, provides an assessment and proposes a scenario for activating points of economic growth. Cooperation of productive capacities that contribute to production of a variety of innovative marketable products will activate the points of economic growth. The natural energy potential of the Republic of Bashkortostan is limited in terms of oil, natural gas and coal, while the unique petrochemical and oil refining facilities located on this territory contribute to development of production and scientific potential in the field of hydrocarbons. Therefore, the production of hydrocarbons from renewable energy sources based on sugar and oil crops contributes to the economic growth of certain specializations of the agro-industrial and machine-building profile and partial provision of raw materials to the production specialization of the petrochemical and oil refining profile.
\end{abstract}

\section{Introduction}

The economic development of the territory depends on many factors, the main ones being labor and natural resource potentials. With the reduction of the natural resources potential, migration processes begin, contributing to a slowdown in the economic development of the territory. Hence, it becomes necessary to search for such a potential that would optimize labor resources and contribute to sustainable development and increase in gross domestic product. Placing production facilities on a separate territory leads to an increase in labor resources. However, over time, the population of all categories in this area increases. Obviously, in such territories it is necessary to activate the points of economic growth, contributing to the maintenance of the life support of this territory and the development of the created production capacities. Sustainable development management of these territories is a public administration task. In turn, public administration uses incentive tools, for example, through institutions (norms) for all those to whom these norms are addressed [1]. Thus, such tools are needed that allow activating the points of economic growth in the polar territory with a reduction in natural resources potential with prospects of their activation.

\footnotetext{
*Corresponding author: olgaf79@mail.ru
} 
The territory of the Republic of Bashkortostan, as a region of the Russian Federation, is a vivid example of the polarization of production capacities of specialization in the petrochemical and oil refining profile [2]. A decrease in the production of natural resources potential - traditional oil in the region [3] and a decrease in their proven reserves not only on the territory of the Russian Federation and the world as a whole [4-7], make it possible to ascertain the existing risks of the development of this territory in the future. It should be noted here that we are talking about traditional oil in a liquid state.

To activate the points of economic growth, let us consider renewable energy sources. The authors of [8] consider a non-linear causal relationships between renewable energy sources, economic growth and unemployment using the example of the Republic of Tunisia.The results showed the existence of a general relationship between the data of these countries, which made it possible to recommend authors to create innovative projects and invest in this profile to create jobs for graduates of specialized higher and secondary vocational institutions. Their predecessors in [9] explained that one-dimensional and multidimensional nonlinear models are the best way to construct a function that "is almost certainly nonlinear."

\section{Materials and methods}

Based on existing tools, including methods, models and methods of economic research, it is proposed to analyze, evaluate and select a scenario for activating points of economic growth in the polar territory with a reduction in natural and economic potential and prospects of their activation. Those research methods and models include the accidental growth theory by G. Allison and E. Glazer, T. Holmes and Stevens [10]; the innovative regional growth model by A. Anderson and G. Mantsinen [11]; the empirical model by D. Davis and D. Weinstein [12]; the input-output model by V. Leontiev [13]; the model «volcano» by H. Hirsch [14].

Using the automated method of spatial economic research [15] on the basis of work [16], we will analyze, evaluate and consider the scenario of activating the points of economic growth in the territory of the Republic of Bashkortostan.

The statistical data of "Bashkortostanstat" [17] will serve as the basis for the analysis of the technical and economic indicators of the territory, namely, the population, gross domestic product. The period under review is mainly 2015 - 2020, taking into account market volatility. In addition, we used archival statistical data for the period 1932 - 2017, described in work [3]. The average annual indicators of the US dollar of the Central Bank of the Russian Federation will provide an independent assessment of the current state of the gross domestic product.

For the analysis and visualization of statistical data, the SigmaPlot program was used.

\section{Results and Discussion}

An analysis of the data of work [3] showed that for the period 1932-1968, the trend in oil production in the territory of the Republic of Bashkortostan increased, and from 1968 to 2017 it significantly decreased. At the same time, according to [2], the design production capacity of oil refineries in the regions of the Russian Federation in the Republic of Bashkortostan takes a leading position. Undoubtedly, the location of production facilities of specialization in the petrochemical and oil refining profile is concentrated on the territory of the Republic of Bashkortostan. However, a decrease in oil production in this area may lead to the risk of economic growth in the region. 
Currently, according to statistical data [17], the resident population in the territory of the Republic of Bashkortostan for the period from 2015 to 2020 decreased by $0.83 \%$. Including the urban population increased by $0.39 \%$, the rural population decreased by $0.97 \%$. At the same time, the labor population has a tendency to decline, so for the same period the decline was $7.65 \%$. The dynamics of the population in the Republic of Bashkortostan is shown in Figure 1.

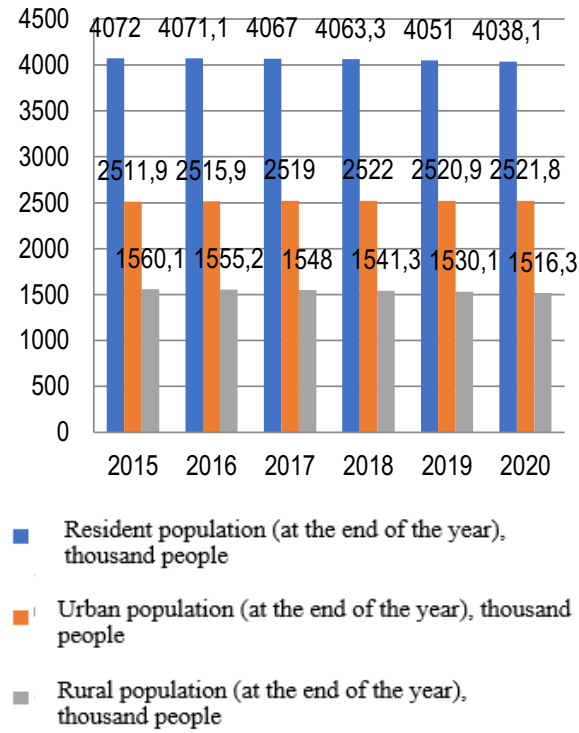

a)

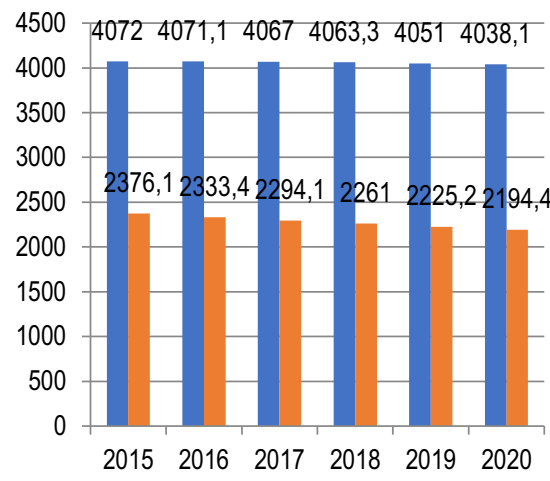

Resident population (at the end of the year), thousand people

- Working-age population (at the end of the year), thousand people

b)

Fig. 1. Population in RB in the period 2015-2020: a - changes in permanent, urban and rural population; $b$ - changes in permanent and working population

Using the SigmaPlot program in Figures 2 and 3, models were built in threedimensional space with the following indicators (time, gross domestic product and population), while the gross domestic product is considered both in rubles and in US dollars.

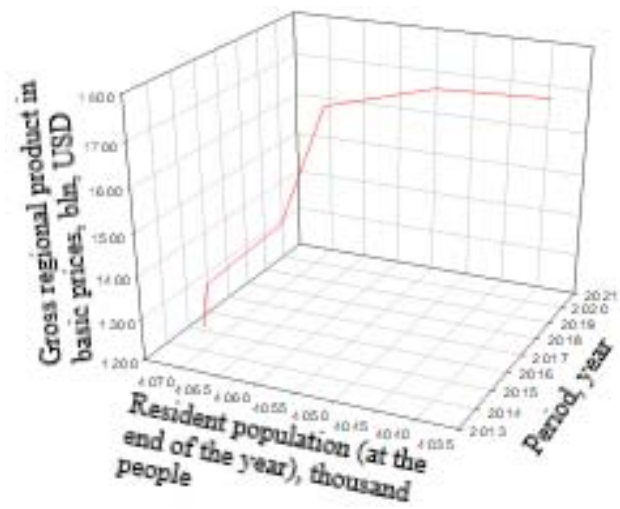

Fig. 2. Time series of gross domestic product (rubles), population of the Republic of Bashkortostan for the period 2014-2020

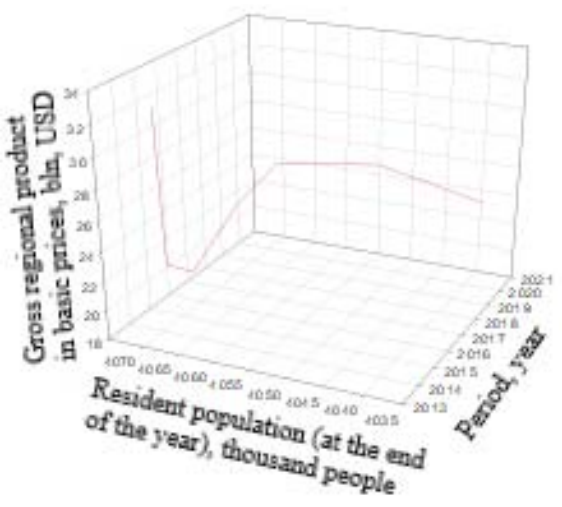

Fig. 3. Time series of gross domestic product (U.S. dollar), population of the Republic of Bashkortostan for the period 2014-2020-2020 
The time series of the three-dimensional model of gross domestic product in rubles and population, Figure 3, shows that for the period 2014 to 2020, the population is declining, but there is an increase in the gross regional product. Hence, it can be assumed that there is economic growth per head of the population living in the region.

A model with the same indicators, only taking into account the average annual US dollar exchange rate (Figure 4) shows that in 2014 the gross domestic product and population for the study period were the maximum values, then there is a dynamics of a sharp decline and in subsequent years a smooth growth of gross domestic product ... However, there is currently a downward trend in the gross domestic product and population. Consequently, there is a slowdown in economic development per head of the population, which negatively affects the economic growth of the territory and the welfare of the population.

Based on the above figures 2 and 3, we can conclude that to assess the economic growth of a territory, it is necessary to consider the models both in ruble terms and in dollars. An independent assessment of the US dollar showed a downward trend in the gross domestic product, which is a consequence of the decline in the population. Thus, we can assume a slowdown in the economic growth of the territory of the Republic of Bashkortostan as a whole.

Taking into account the above, it is necessary to consider the natural resource potential of the region, contributing to further functioning of production facilities of the petrochemical and oil refining profile, and contributing to activation of other production specializations of the territory, for example, the agricultural profile with prospects of their activation.

The main raw materials for production facilities specializing in petrochemical and oil refining are hydrocarbons. As we all know, hydrocarbons are organic compounds made up of carbon and hydrogen atoms. At present, they are obtained from both non-renewable natural sources of oil, natural gas and coal, and renewable - oil and sugar crops.

On the territory of the Republic of Bashkortostan, the energy natural resources potential is limited in terms of oil, natural gas and coal. Let us consider its territory as theoretically suitable for the cultivation and industrial production of oil and sugar crops. Figure 3, according to [17], shows the dynamics of acreage on the territory of the Republic of Bashkortostan for the period 2015-2019, which tends to decline. From 2015 to 2019, it decreased by $6.1 \%$. These sown areas could become industrial production of crops for production of hydrocarbons, which in turn will intensify the activities of territorial agroindustrial specialization.

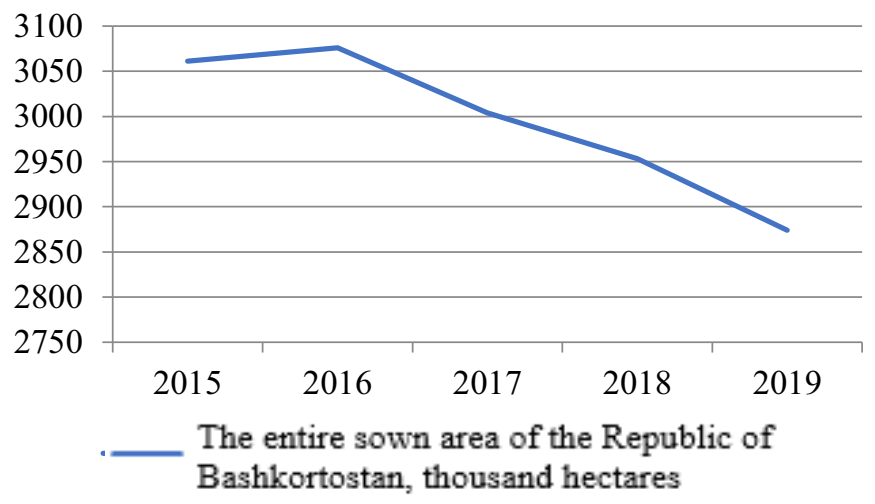

Fig.5. Sown area of the Republic of Bashkortostan for the period 2015-2019 
The paper [18] analyzes the prices of diesel fuel, rapeseed oil, and conventional mixed fuel (biofuel), as a percentage of weight parts 95:5; 90:10. In this work, a graph of dependence of price changes on the period is constructed using the software product Excel V. 2019. In turn, the forecast shows that the price of biofuels, in particular biodiesel, will be slightly higher than the price of traditional diesel, and in times of the crisis, the price of biodiesel will be less than that of traditional diesel fuel, which may help to slow down inflationary processes.

In addition to the production capacities of the specialization of the petrochemical and oil refining profile, buses and concrete pumps are produced in the region, which occupy 4th and 1st places in the all-Russian production as of 2019 [17]. By activating machinebuilding specialization for the agro-industrial complex, the region can become a leader in the all-Russian production of innovative products from hydrocarbons, for example, biofuels, as well as maintain a leading position in machine building, which in turn affects the economic growth of the region as a whole.By activating machine-building specialization for the agro-industrial complex, the region can become a leader in the allRussian production of innovative products from hydrocarbons, for example, biofuels, as well as maintain a leading position in machine building, which in turn affects the economic growth of the region as a whole.

\section{Conclusion}

Firstly, in order to activate points of economic growth, it is necessary to consider the existing potential of production facilities. Secondly, in particular for the Republic of Bashkortostan, with a decrease in oil production and the leading production capacities of specialization of the petrochemical and oil refining profile, it is necessary to consider the option of obtaining hydrocarbons from renewable energy sources, such as the production of sugar-containing and oil crops in free sown areas, in order to produce innovative products, for example, biofuels at these facilities. Thirdly, development of this direction suggests activating the production of machine-building production for the agro-industrial complex, which in turn contributes to the economic growth of the region.

\section{Acknowledgements}

The authors express their deep gratitude to the teaching staff of FSBEI of HE "Ufa State Petroleum Technological University", who kindly provided information for writing this article.

\section{References}

1. T.V. Duran, V.A. Kostin, Society and Power, 2 (30), 10 (2011)

2. O.A. Fedorova, Sh.Z. Valiev, Current state, trends and innovative technologies in the development of the agro-industrial complex: materials of the international scientific and practical conference in the framework of the XXIX International specialized exhibition “Agrocomplex-2019”, 224 (2019)

3. Chronicle of Bashkir oil (1932-2007), 400 (2007)

4. BP Statistical Review of World Energy, https://www.bp.com/

5. OPEC Bulletin (1997-2014), http://www.opec.org 
6. B. -Zh. Zhambalnimbuev, Bulletin of the Accounts Chamber of the Russian Federation, 3 (195), 3 (2014)

7. State report "On the state and use of mineral resources in the Russian Federation in 2016 and 2017", https://www.mnr.gov.ru/

8. M. Ben Mbarek, I. Abdelkafi, R. Feki, J Knowl Econ, 9, 694 (2018)

9. Clive Granger, John William, Paul Newbold, Forecasting economic time series (2014)

10. G. Ellison, E. Glaser, Journal of Political Economy, 105, 889, 13 (1997)

11. A.E. Andersson, J. Mantsinen (1980). Systems Research, 25 (5), 353

12. Donald R. Davis, David E. Weinstein, American Economic Review, 92 (5), 1269 (2002)

13. W. Leontief, Weltwirtschaftliches Archiv, 22, 2, 338, 265* (1925)

14. H. Giersch, Weltwirtschaftskrise Archiv, 115, 4 (1979)

15. Sh. Z. Valiev, O.A. Fedorov; Pat. No. 2710914 Russian Federation, IPC G06Q 10/04] /; applicant and patent holder Federal State Budgetary Educational Institution of Higher Education "Ufa State Petroleum Technical University" (RU) - 2018139688; declared 11/08/2018; publ. 01/14/2020. Bul. No. 2 - 2 p.)

16. S.Z. Valiev, O.A. Fedorova, Journal of Engineering and Advanced Technology, 3 (8), 121 (2019)

17. Statistical reference book of the Republic of Bashkortostan 2015-2019, https://bashstat.gks.ru/

18. O.A. Fedorova, S.Z. Valiev, Frontier Information Technology and Systems Research in Cooperative Economics, Studies in Systems, Decision and Control, 316 (2021) 